\title{
FARKLI ORANLARDA MERCİMEK UNU VE PATATES NİŞASTASI İÇEREN KARIŞIMLARIN EKSTRÜDE ÇABUK ERIŞTE ÜRETİMINDE KULLANIMININ İNCELENMESİ
}

\author{
Merve Vatansever ${ }^{2}$, Burcu Havva Tığa ${ }^{2}$, Seher Kumcuoğlu ${ }^{*}$, Şebnem Tavman ${ }^{1}$ \\ ${ }^{1}$ Ege Üniversitesi, Gıda Mühendisliği Bölümü, 35100 Bornova, İzmir, Türkiye \\ ${ }^{2}$ Ege Üniversitesi, Fen Bilimleri Enstitüsü Gıda Mühendisliği Anabilim Dalı, 35100 Bornova, İzmir, Türkiye
}

Geliş / Received: 12.03.2020; Kabul / Accepted: 20.07.2020; Online bask1 / Published online: 15.08.2020

Vatansever, M., Tiğa, B.H., Kumcuoğlu, S., Tavman, Ş. (2020). Farklı oranlarda mercimek unu ve patates nişastası içeren karışımların ekstrüde çabuk erişte üretiminde kullanımının incelenmesi. GIDA (2020) 45(5) 837-849 doi: 10.15237/gida.GD20041

Vatansever, M., Tiğa, B.H., Kumcuoğh, S., Tavman, Ş. (2020). Investigation of the use of lentil flour and potato starch blends in the production of extruded instant noodles. GIDA (2020) 45(5) 837-849 doi: 10.15237/gida.GD20041

\section{ÖZ}

Bu çalışmada, ekstrüde çabuk erişte üretiminde kırmızı mercimek (Lens culinaris) unu ile patates nişastası sırasıyla 90:10, 80:20, 70:30 ve 60:40 oranlarında kullanılmıştır. Ayrıca guar zamkı ilavesinin (\%2) erişte kalitesine etkisi incelenmiştir. Mercimek unu oranının artması eriştelerin pişme süresinin azalmasına, pişme kaybı ve su absorbsiyonu değerlerinin ise artmasına neden olmuştur $(P<0.05)$. Eriştelerin sertlik değerleri 2220.72-4391.67 g; yapışkanlık değerleri 0.54-0.78 arasında değişmiştir. Artan mercimek unu oranıyla eriştelerin $L^{*}$ değeri azalırken, $a^{*}$ değerinin arttı̆̆ gözlenmiştir. Guar zamkı içeren erişte örneklerinin daha pürüzlü yüzey mikroyapısına sahip olduğu görülmüştür. Guar zamkı ilavesi içeren 80:20 oranına sahip örneğin (GM80) diğer örneklere göre daha iyi kalite kriterlerine sahip olduğu belirlenmiştir.

Anahtar kelimeler: mercimek unu, patates nişastası, guar zamkı, çabuk erişte, ekstrüzyon pişirme

\section{INVESTIGATION OF THE USE OF LENTIL FLOUR AND POTATO STARCH BLENDS IN THE PRODUCTION OF EXTRUDED INSTANT NOODLES}

\begin{abstract}
In this study, red lentil (Lens culinaris) flour and potato starch were used in the production of extruded instant noodles in the ratios of 90:10, 80:20, 70:30 and 60:40, respectively. Furthermore, the effect of addition of guar gum $(2 \%)$ on the quality of noodles was investigated. The increase in the ratio of lentil flour caused a decrease in the cooking time of the noodles, and an increase in the cooking loss and water absorption values $(P<0.05)$. The hardness values of the noodles ranged from 2220.72 to $4391.67 \mathrm{~g}$ and cohesiveness values ranged from 0.54 to 0.78 . The $L^{*}$ value of the noodles decreased while the $a^{*}$ value increased with the increasing lentil flour ratio. The noodle samples containing guar gum demonstrated a rougher surface microstructure. It was concluded that the noodle sample with the ratio of 80:20 (GM80) with guar gum had better quality characteristics compared to other samples. Keywords: lentil flour, potato starch, guar gum, instant noodle, extrusion cooking
\end{abstract}

\footnotetext{
${ }^{*}$ Yazışmalardan sorumlu yazar / Corresponding author

$\square$ seher.kumcuoglu@ege.edu.tr 淈: (+90) 2323113023

圆: (+90) 2323114831
}

Merve Vatansever ORCID ID: 0000-0002-4138-4851

Burcu Havva Tığa ORCID ID: 0000-0001-6222-7735

Seher Kumcuoğlu ORCID ID: 0000-0002-3663-2881

Şebnem Tavman ORCID ID: 0000-0002-6042-7482 


\section{GİRIŞ}

Günümüz dünyasının yaşam koşullarının ağırlaşması ve zamanın önem kazanmasıyla birlikte hazırlanması kolay ve çabuk olan gidalara da ilgi artmaktadır. Erişte ise tüm dünyada oldukça sevilen ve çok tüketilen bir besindir. Ayrıca erişte, kolay pişirme yöntemlerine, arzu edilen duyusal özelliklere, uzun raf ömrüne, uygun fiyata ve 4000 ylı aşkın bir geçmişe sahip olması nedeniyle, Asya ülkelerinin birçok yerinde yaygın olarak kullanılan başlıca gıdalardan biridir (Rathod ve Annapure, 2017). Çabuk erişteler genellikle mutfakta minimum hazırlık ile pişirmek üzere tasarlanmış hazır gıdalar grubunda siniflandirilmaktadır (Cho vd., 2010; Kumoro vd., 2016). Bununla birlikte, erişte enerji ve nişasta açısından zengin olmasına karşın lif ve bazı önemli besin bileşenlerince fakir, tüketime hazır bir gıdadır (Gernah vd., 2011). Sağlıklı beslenme konusunda bilinçli tüketicilerin lif ile protein içeriği yüksek ve yağ içeriği düşük olan ürünlere olan talebi; üreticileri zengin besin içeriğine sahip ve kaliteli ürünler geliştirmeye yönlendirmiştir (Dewi, 2011). Bu doğrultuda, baklagiller hem kan basınc1 ve kardiyovasküler hastalıklara yakalanma riskini azaltmak için yararlı hem de protein, lif ve düşük glisemik indeksli karbonhidrat kaynağ1 olabilmektedirler (Lee vd., 2008). Bakliyat tohumlarının diyet lif içeriği 140 ile $530 \mathrm{~g} / \mathrm{kg}$ arasında değişmektedir ve bu değer tahıllardan daha yüksektir (Frias vd., 2011; Hall vd., 2017). Baklagil bitki ailesinden olan kırmızı mercimek yaklaşık \%12 oranında lif içeriğine sahiptir ve yararlı bağırsak bakterilerinin gelişimini desteklemektedir (Stephen vd., 1995). Bununla birlikte, mercimek $\% 25$ in üzerinde protein içerir ve bu nedenle mükemmel bir et alternatifi olarak değerlendirilmektedir (Ganesan ve Xu, 2017). Farklı baklagil unları ilave edilerek üretilen makarnaların besin değerlerinin arttığ1 bildirilmiştir (Bouasla vd., 2017). Aynı zamanda, baklagil unları, doğal renklendirici bileşenler olarak da kullanilabilmektedir. Makarna örneklerinde, renklendirici bileşen olarak farklı baklagil unlarının kullanılmasının araştııldığı bir çalışmada, mercimek ununun en uygun renklendirici bileşen olduğu belirtilmiştir (Teterycz vd., 2020). Literatürdeki çalışmalar göz önüne alındığında, baklagillerin alternatif ürünlerde kullanılması tüketicilerin baklagillere olan talebini artırabileceğini ve böylece pazarnn gelişmesine katk1 sağlayabileceğini düşündürmektedir.

Erişte üretiminde kullanılan nişasta, pişirme sırasında yapiyı koruyan ağ olarak işlev görmektedir (Mestres vd., 1988). Patates nişastas1, eriştelerin uygun bir doku ve görünüme sahip olmasını sağlar (Noda vd., 2006). Ayrica patates nişastası, eriştelerde pişirildikten sonra belirgin ve parlak bir görünüm kazandırır; pürüzsüz ve düzgün bir doku sağlaması nedeniyle de, çorba ve soslarda yüksek absorbsiyon yeteneğine sahiptir (Kim vd., 1996). Zamklar/hidrokolloidler nişasta esaslı ürünlerde yaygın olarak stabiliteyi artırmak, dokuyu geliştirmek ve işlemeyi kolaylaşturmak için kullanılmaktadır (Kaur vd., 2015). Guar zamk1 (Cyamopsis tetragonolobus, Leguminosae), genellikle guar fasulyesi ad1 verilen ylllk bir bitkinin tohumlarının öğütülmüş endosperminden elde edilmektedir (Fox, 1997). Guar zamkının makarna/erişte üretiminde kullanılması, esas olarak gida matrislerine su bağlayarak veya lif olarak kullanarak kalınlaştırma ve stabilize etme özelliğine dayanmaktadır (Brennan ve Tudorica, 2008). Yu ve Ngadi (2006) guar zamkının kızartılmış hazır eriştelerin kohezyonunu ve mekanik gücünü (reolojik özelliklerini) artırdığını bildirmiştir. Guar endospermi, toplam diyet lifi (TDF)'nin çözünür diyet lif (SDF) kısmına katkıda bulunan suda çözünür bir zamk kaynağıdır (Mudgil vd., 2014). Gidaların glisemik indeks değerleri, nişasta olarak kullanılan hammaddelerin kaynağına göre değişebilmektedir ve gida işlemede hidrokolloidlerin varlığ1 ile bu değer azaltılabilmektedir (Gularte ve Rosell, 2011).

Ekstrüzyon pişirme tekniği, ön pişirilmiş makarna veya makarna benzeri ürünler üretmek için kullanılabilmektedir. Bu ürünler servis edilmeden önce geleneksel pişirme işlemine ihtiyaç duymaz ve hazırlık için sadece kısa bir süre için sıcak su ilave edilmesini gerektirmektedir (Wójtowicz ve Mościcki, 2014). Gida ekstrüzyonu, g1da endüstrileri için değişen şekil, boyut, tat ve dokuya sahip çok sayıda ürünü işlemek ve üretmek için umut verici bir teknolojidir (Kaur vd., 2010). Bu yüzden ekstrüzyon işlemi, erişte üretimi için 
verimli ve uygulanması kolay bir yöntem olarak kullanılmaktadır. Ayrıca, ekstrüzyonla pişirme, nişastaların jelatinize olduğu, proteinlerin denatüre edildiği ve ekstrüdatların dokusal ve histolojik olarak yeniden yapılandırıldığ1 yüksek sıcaklıkta ve kısa sürede (HTST) gerçekleşen bir işlemdir (Smith, 1971). Ekstrüzyonla pişirme işleminde, uygun bir ekstrüde ürün elde etmek için işlem parametrelerinin kontrol edilmesi önemlidir (Singh vd., 2006). Gıda endüstrisinde kullanılan üç önemli ekstrüder çeşidi vardır: pistonlu ekstrüderler, makaralı ekstrüderler ve vidalı ekstrüderler. Vidalı ekstrüderler, günümüzde en s1k kullanılan ekstrüderlerdir; tek ve çift vidalı ekstrüderler olarak kategorize edilebilirler. Tek vidalı ekstrüzyon pişirmenin, düşük maliyeti nedeniyle makarna ürünlerini yapmak için cazip bir yöntem olduğu belirtilmektedir (Alam et al., 2016). Çift vidalı ekstrüderler, tek vidalı ekstrüderlerden daha karmaşıktır ancak çok daha fazla esneklik ve daha iyi kontrol sağlamaktadır (Riaz, 2001).

Kuru baklagillerin zengin protein ve lif içeriği nedeniyle bu ürünleri zenginleştirme amaciyla kullanılması giderek yaygınlaşmaktadır. Gıdalanın besinsel içeriği ve çabuk hazırlanabilmesi tüketicilerin seçimleri üzerinde etkili olan ölçütlerdendir. Bu çalışmada, kullanımı giderek yaygınlaşan çabuk erişte üretiminde kırmızı mercimek ununun kullanımı araştırılmıştır. Farklı oranlarda kırmızı mercimek unu ve patates nişastası içeren karışıma \%2 oranında guar zamkı eklenerek üretilen erişte örneklerinin pişme özellikleri, mikroyapı özellikleri, renk değerleri, suya geçen madde miktarı ve pişmiş ürünün doku özelliklerinin belirlenmesi ve guar zamk1 içermeyen örneklerle karşılaşturılması sonucu, formülasyolann çabuk erişte üretiminde kullanımının incelenmesi amaçlanmıştır.

\section{Materyal ve Yöntem \\ Materyal}

Çalışmada gerçekleştirilen denemeler için erişte üretiminde kullanılan mercimek unu Çınarım Ekmekçilik Mamulleri (İzmir, Türkiye); patates nişastas1, Hasal Tarım Ürünleri (İzmir, Türkiye); guar zamk1 Biokim \& Wenda Kimya (İmir, Türkiye); tuz $(\mathrm{NaCl})$ yerel bir marketten temin edilmiştir. Mercimek ununun bileşimi üretici firma tarafindan $\% 8.65 \mathrm{nem}, \% 24.5$ protein, $\% 2.6$ kül, \%1.5 yağ olarak bildirilmiştir.

\section{Örnek hazırlama}

Çalışmada sekiz farklı erişte formülasyonu hazırlanmıştır. İlk dört formülasyonda, mercimek unu ve patates nişastası karışımı için 90:10 (M90), 80:20 (M80), 70:30 (M70) ve 60:40 (M60) oranlar1 kullanılmış ve karışıma \%2.5 oranında tuz ilave edilmiştir. Diğer dört formülasyonda ise aynı formülasyonlara $\% 2$ oranında guar zamk1 (GM90, GM80, GM70, GM60) eklenmiştir (Çizelge 1). Bileşenler Kitchen Aid Mikser (St. Joseph, Mich., ABD) ile 250 d/dak'da 5 dakika boyunca karıştırılmış ve ekstrüdere beslenmiştir.

\section{Ekstrüzyon pişirme}

Erişte örnekleri, eş yönlü dönen çift vidalı laboratuvar tipi ekstrüder (Feza Makine Ltd Şti., İstanbul, Türkiye) kullanılarak üretilmiştir. Ekstrüder, 25:1 boy:çap (L:D) oranına ve 7x1 mm (delik sayısı x delik çapı) kalıp çapına sahiptir.

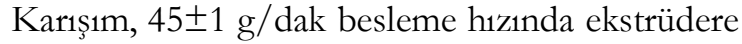
beslenmiştir. Besleme nem içeriği \%35 olarak ayarlanmış ve vida hızı 100 d/dak'da sabit tutulmuştur. Ekstrüderin dört kovan bölgesinin s1caklıklarr; ilk bölge $50^{\circ} \mathrm{C}, 2$. bölge $70^{\circ} \mathrm{C}$, 3 . bölge $90^{\circ} \mathrm{C}$, 4. bölge ve kalıp sicaklığ $80^{\circ} \mathrm{C}$ olacak şekilde ayarlanmıştır. Ekstrüderden çıkan örnekler, $105^{\circ} \mathrm{C}^{\prime} \mathrm{de}$ nem değeri \% $\%-7$ olana kadar (60-70 dak.) sicak hava ile etüvde (Memmert UN110, Almanya) kurutulmuştur.

\section{Pişme özellikleri}

Pişme özelliklerinin belirlenmesi için $500 \mathrm{~mL}$ 'lik behere $25 \mathrm{~g}$ örnek tartılmıs, $450 \mathrm{~mL} 100^{\circ} \mathrm{C}$ saf su ilave edilerek beherin ağz1 saat camı ile kapatılmıştır. Pişme sırasında 10 saniye aralıklarla erişte örneği alınarak iki cam levha arasında sıkıştırılmış, ortasındaki beyaz iç kısım kaybolunca işlem sonlandırılmıştır. Belirlenmiş olan süre erişte örneklerinin pişme süreleri olarak kaydedilmiştir. Pişme süresi kadar bekletilen örnekler süre sonunda 500 mL'lik behere süzülmüş ve durulanmıştır. Daha sonra süzülen örnekler tartılmıs ve pişme ağırlığını hesaplamak için sonuçlar kaydedilmiştir. Pişme suyu ve durulama suyu, saf su ile 500 mL'ye 
tamamlanmıştır. Bu kanışımın 50 mL'si önceden darası alınmış 100 mL'lik behere alınarak $105^{\circ} C^{\prime}$ deki etüvde (Memmert UN110, Almanya) sabit tartıma gelene kadar kurutulmuştur. Pişme kaybı kuru ağırlığa göre rapor edilmiştir (AACCI, 2000).

Çizelge 1. Erişte örneklerinin formülasyonu

Table 1. Formulas of noodle samples

\begin{tabular}{lcccc}
\hline $\begin{array}{l}\text { Örnek } \\
\text { Samples }\end{array}$ & $\begin{array}{c}\text { Mercimek } \\
\text { unu }(\mathrm{g}) \\
\text { Lentil flour }(\mathrm{g})\end{array}$ & $\begin{array}{c}\text { Patates } \\
\text { nişastas1 }(\mathrm{g}) \\
\text { Potato starch(g) }\end{array}$ & $\begin{array}{c}\text { Guar } \\
\text { zamk1 }(\mathrm{g}) \\
\text { Guar gum }(\mathrm{g})\end{array}$ & $\begin{array}{c}\text { Tuz }(\mathrm{g}) \\
\text { Salt }(\mathrm{g})\end{array}$ \\
\hline M90 & 90 & 10 & - & 2.5 \\
M80 & 80 & 20 & - & 2.5 \\
M70 & 70 & 30 & - & 2.5 \\
M60 & 60 & 40 & - & 2.5 \\
GM90 & 90 & 10 & 2 & 2.5 \\
GM80 & 80 & 20 & 2 & 2.5 \\
GM70 & 70 & 30 & 2 & 2.5 \\
GM60 & 60 & 40 & 2 & 2.5 \\
\hline
\end{tabular}

M90: Örneğin mercimek unu oran1 \%90, M80: Örneğin mercimek unu oran1 \%80, M70: Örneğin mercimek unu oranı \%70, M60: Örneğin mercimek unu oranı \%60, GM90: \%2 guar zamk1 içeren örneğin mercimek unu oranı \%90, GM80: \%2 guar zamk1 içeren örneğin mercimek unu oranı \%80, GM70: \%2 guar zamk1 içeren örneğin mercimek unu oranı \%70 GM60: \%2 guar zamk1 içeren örneğin mercimek unu oranı $\% 60$

M90: sample containing 90\% red lentil flour, M80: sample containing 80\% red lentil flour M70: sample containing $70 \%$ red lentil flour, M60: sample containing 60\% red lentil flour GM90: sample containing 90\% red lentil flour + $2 \%$ guar gum, GM80: sample containing $80 \%$ red lentil flour $+2 \%$ guar gum, GM70: sample containing $70 \%$ red lentil flour $+2 \%$ guar gum, GM60: sample containing $60 \%$ red lentil flour $+2 \%$ guar gum

\section{Doku özellikleri}

Erişte örneklerinin doku özellikleri, $35 \mathrm{~mm}$ silindirik prob $(\mathrm{P} / 35)$ ve $5 \mathrm{~kg} \mathrm{l}^{\prime} \mathrm{lk}$ bir yük hücresi kullanılarak doku analiz cihazı (TA.XTExpress; Stable Microsystems, Surrey, UK) ile belirlenmiştir. Daha önceden belirlenen pişme süresi kadar pişirilen erişte örnekleri test platformuna birbirine paralel şekilde beşer adet olarak yerleştirilmiş ve $2 \mathrm{~mm} / \mathrm{s}$ test hızında orjinal kalınlığının \%75'ine sıkıştırılmıştır. Birinci ve ikinci sıkıştırma arası 2 saniyedir. Deformasyon için gerekli kuvvet olan sertlik (hardness); ilk sıkıștırma sırasındaki maksimum kuvvet, elastikiyet (springiness); ikinci sıkıştırmadaki mesafenin (2. uzunluk) ilk sıkıştırmadaki mesafeye (1.uzunluk) oranı, yapişkanlık (cohesiveness); ikinci sıkıştırmadaki alanının birinci sıkıştırmadaki alana oranı (Alan 2/Alan 1) olarak belirlenmiştir. Her örnek için en az sekiz ölçüm kaydedilmiştir (Choy vd., 2013).

\section{Renk özellikleri}

Hazır erişte örneklerinin renk değerleri Minolta Colour Reader (CR-10 Japan) ile CIE $L^{*}, a^{*}, b^{*}$ renk sistemi kullanılarak belirlenmiştir. Yaklaşık $15 \mathrm{~g}$ erişte örneği öğütülerek şeffaf kilitli poşetlere konulmuş ve poşet yüzeyinden en az sekiz ölçüm alınarak ortalama değerler hesaplanmıştır (Choy vd., 2012).

\section{Genişleme oranı}

Erişte örneklerinin çapı dijital kumpas kullanılarak ölçülmüştür. Genişleme oranı, Eşitlik 1'de verilen erişte kesit alanının, kalıp kesit alanına oranı olarak hesaplanmıştır (Alvarez-Martinez vd., 1988):

$$
\text { Genişleme oranı }=D^{2} / d^{2}
$$

Burada; D: erişte çapını (mm), d: ekstrüder kalıp çapını (mm) göstermektedir. 


\section{Yığın yoğunluğu}

Yığın yoğunluğu, ticari erişte üretimi açısından önemli bir kalite özelliğidir. Yığın yoğunluğu, erişte çapı ve uzunluğu kullanılarak 8 rastgele ölçüm olacak biçimde dijital kumpas ile belirlenmiştir. Erişte örneklerinin ağırllk ölçümü için analitik bir terazi kullanılmıştır. Yığın yoğunluğu değeri, Eşitlik 2 ile elde edilmiştir (Ding vd., 2005):

$$
Y \iota \breve{g} \text { ln yoğunluğ } u=4 m / \pi D^{2} L
$$

Burada; $m$ : erişte ağıllı̆̆ını (g), D: erişte çapını $(\mathrm{mm})$, L: erişte uzunluğunu $(\mathrm{mm})$ göstermektedir.

\section{Su absorbsiyon indeksi (WAI) ve suda çözünürlük indeksi (WSI)}

WAI ve WSI değerleri, Ding vd. (2005) tarafindan belirtilen yönteme göre belirlenmiştir. $2.5 \mathrm{~g}$ erişte örneğine (<60 mesh) $30 \mathrm{~mL}$ damıtılmıss su ilave edilmiş ve oluşan süspansiyon 30 dakika (ara ara çalkalanarak) bekletilmiştir. Çözelti $2500 \mathrm{~g}$ kuvvetinde 20 dakika santrifüj (Hettich Universal 320R cooled, Almanya) edilmiştir. Sıvı faz, darası bilinen bir kurutma kabına alınarak sabit tartıma gelene kadar kurutulmuş ve birim ağılıktaki WSI hesaplanmıştır. WSI, süpernatant içindeki çözünmeyen katı maddelerin, örneğin ağırllğının bir yüzdesi olarak ifade edilen ağıllıktır. Tüpte kalan jel tartılarak WAI değerinin hesaplanmasında kullanılmıştır.

\section{Mikroyap1}

Eriştelerin yüzey mikroyapısı, taramalı elektron mikroskobu (SEM) kullanılarak belirlenmiştir. Örneklerin yüzeyi, karbon kaplı bant yardımı ile staplara yapıştırılarak saf altın ile kaplanmış (Leica EM ACE600, Almanya) ve daha sonra taramalı elektron mikroskobu (Thermo Scientific Apreo S, $\mathrm{ABD})$ ile görüntülenmiştir. Örnek yüzeylerinin görüntülenmesinde $150 \mathrm{X}$ ve 1000X büyütme oranları kullanılmışur.

\section{İstatistiksel analiz}

Elde edilen sonuçlara SPSS paket programı (SPSS 25, IBM, ABD) kullanılarak tek yönlü varyans analizi uygulanmış ve sonuçlar $P \quad<0.05$ seviyesinde değerlendirilmiştir. Denemeler arasındaki farkları karşılaştırmak amacıyla Duncan çoklu karşılaştırma testi uygulanmıştır. Sonuçlar ortalama \pm standart sapma olarak verilmiştir.

\section{Sonuçlar ve tartışma \\ Pişme özellikleri}

Erişte örneklerinin pişme özellikleri Çizelge 2'de verilmiştir. Erişte örneklerinin pişme süreleri 1.55-5.15 dak arasında değişim göstermiştir. Mercimek unu oranı azaldıkça, pişme süresinde artşs görülmüştür $(P<0.05)$. Azalan mercimek unu oranıyla birlikte eklenen nişasta oranının artmasına bağlı olarak toplam amiloz içeriği de artmaktadır. Park ve Baik (2004) tarafindan yapılan bir çalışmada, amiloz içeriğinin artmasıyla birlikte optimum su absorbsiyonunun azaldığı ve eriştelerin pişme süresinde artş gerçekleştiği bildirilmiştir. Bununla birlikte, guar zamkının ilavesi pişme süresi değerlerinin artmasına neden olmuştur $(P<0.05)$. Zamk ilavesinin daha uzun pişme süresine neden olması, suyun erişte şeritlerinde bulunan nişasta granüllerine sınırlı absorbsiyonuna bağlanabilmektedir (Kaur vd., 2015). Ayrıca eriştelerin patates nişastası oranlarına bağlı olarak değişen pişme süreleri, patates nişastasının düşük jelatinizasyon sıcaklığından kaynaklanabilmektedir (Singh vd., 2002).

Erişte örneklerinin pişme kaybı değerleri \%6.688.79 arasında değişmektedir. Pişme sırasında minerallerin suya geçmesi makarna ürünlerinde son ürününün beslenme kalitesini düşürmektedir (Schoenlechner vd., 2010). Aynca Kim (1996) tarafından erişte için kabul edilebilir pişme kaybı değerinin \%10'dan az olması gerektiğ bildirilmiştir. Erişte örneklerinin pişme kaybı değerleri incelendiğinde, istenilen değer aralığında olduğu görülmektedir. Bununla birlikte, ilave edilen mercimek unu oranının, örneklerin pişme kayb1 değerleri üzerinde anlaml bir etkisi olmuştur $(P<0.05)$. Mercimek unu oranı arttıkça, pişme kaybı değerlerinde artış gözlenmiştir. Artan pişme kayıpları, mercimek ununun lifli bir materyal olması ve nişasta ağının lif varlığı nedeniyle zayıflamasına bağlı olmaktadır (Cabrera-Chávez vd., 2012). Guar zamk1 ilavesiyle $\% 70$ ve $\% 60$ mercimek unu içeren örneklerde pişme kaybı değerlerinin azaldığı gözlenmiştir ( $P$ $<0.05)$. Su absorbsiyonu değerleri \%212.91- 
261.70 aralı̆̆ındadır. Sonuçlar mercimek unu oranı arttıkça, su absorbsiyonun arttığını göstermiştir. Bununla birlikte, erişte örneklerinin su absorbsiyon değeri arttıkça, pişme süresinin azaldığ1 gözlenmiştir. Hatcher vd. (1999) tarafindan yapılan çalışmada da benzer sonuç bulunmuştur. Guar zamkı ilavesi, \%90 mercimek unu içeren örnek dişında, su absorbsiyon değerlerinde artışa neden olmuştur. Aravind vd. (2012)'nin yaptı̆̆ çalışmada \%2.5 oranında guar zamk1 ilavesinin su absorbsiyonuna etkisi gözlenemezken, $\% 5$ oranında guar zamkı ilave edilen makarna örneklerinde ise su absorbsiyonu değerinin zamk içermeyen örneğe göre arttığ1 belirtilmiştir.

\section{Doku özellikleri}

Erişte örneklerinin doku özellikleri Çizelge 2'de verilmiştir. Patates nişastası oranı ve guar zamk1 ilavesinin örneklerin sertlik değerini etkilediği gözlenmiştir. Mercimek unu oranı azaldıkça, sertlik değeri artmıştır. Bu durumun, mercimeğin yüksek protein içeriğine $(\% 22-\% 31)$ (Adsule ve Kadam, 1989) bağlı olduğu düşünülmektedir. Erişte örneklerinin, mercimek unu oranının azalmasıyla yapışkanlık özelliğinin artış gösterdiği saptanmıştur. Bu durumun artan nişasta oranı ile amilopektin içeriğinin artmasının bir sonucu olduğu düşünülmektedir. Amilopektin içeriğinin yüksek olması, erişte hamurunun yapışkan olmasina neden olmaktadir (Afifah ve Ratnawati, 2017). GM90 örneğinde, guar zamk1 ilavesinin yapışkanlık değeri üzerinde anlamlı bir etkisi gözlenmemiştir $(P \quad>0.05)$. Bununla birlikte yapışkanlık değeri, GM80 örneğinde artarken, GM70 ve GM60 örneklerinde azalmıştır ( $P$ $<0.05)$. Elastikiyet değerleri için mercimek unu oranı ve guar zamkı gözetmeksizin erişte örnekleri arasında anlamlı bir fark saptanmamıştır (P $>0.05)$.

Çizelge 2. Erişte örneklerinin pişme ve doku özellikleri

Table 2. Cooking and texture properties of noodle samples

\begin{tabular}{|c|c|c|c|c|c|c|}
\hline \multirow[b]{2}{*}{$\begin{array}{l}\text { Örnek } \\
\text { Sample }\end{array}$} & \multicolumn{3}{|c|}{$\begin{array}{l}\text { Pişme özellikleri } \\
\text { Cooking properties }\end{array}$} & \multicolumn{3}{|c|}{$\begin{array}{l}\text { Doku özellikleri } \\
\text { Texture properties }\end{array}$} \\
\hline & $\begin{array}{c}\text { Pişme } \\
\text { süresi (dak) } \\
\text { Cooking time } \\
\text { (min) }\end{array}$ & $\begin{array}{c}\text { Pişme kaybi } \\
(\%) \\
\text { Cooking loss } \\
(\%)\end{array}$ & $\begin{array}{c}\text { Su absorbsiyonu } \\
(\%) \\
\text { Water Absorption } \\
(\%)\end{array}$ & $\begin{array}{l}\text { Sertlik (g) } \\
\text { Hardness (g) }\end{array}$ & $\begin{array}{l}\text { Yapışkanlik } \\
\text { Cohesiveness }\end{array}$ & $\begin{array}{c}\text { Elastikiyet } \\
\text { Springiness }\end{array}$ \\
\hline M90 & $1.55 \pm 0.07 \mathrm{a}$ & $8.79 \pm 0.42^{c}$ & $261.70 \pm 11.54^{\mathrm{e}}$ & $2220.72 \pm 199.58^{a}$ & $0.54 \pm 0.01^{\mathrm{a}}$ & $0.86 \pm 0.01^{a}$ \\
\hline M80 & $2.25 \pm 0.10^{\mathrm{b}}$ & $8.59 \pm 0.70^{c}$ & $236.71 \pm 1.86^{\mathrm{bcd}}$ & $3863.44 \pm 287.20^{\mathrm{cd}}$ & $0.66 \pm 0.01^{b}$ & $0.88 \pm 0.01^{a}$ \\
\hline M70 & $3.35 \pm 0.07 \mathrm{c}$ & $8.27 \pm 0.73 \mathrm{bc}$ & $226.42 \pm 15.38 \mathrm{abc}$ & $4372.44 \pm 343.95^{\mathrm{e}}$ & $0.76 \pm 0.01 \mathrm{de}$ & $0.86 \pm 0.01^{a}$ \\
\hline M60 & $4.40 \pm 0.07 \mathrm{e}$ & $7.06 \pm 0.52^{\mathrm{ab}}$ & $212.91 \pm 2.40^{a}$ & $4391.67 \pm 247.24^{\mathrm{e}}$ & $0.78 \pm 0.01^{\mathrm{e}}$ & $0.86 \pm 0.01^{a}$ \\
\hline GM90 & $2.25 \pm 0.07 \mathrm{~b}$ & $8.57 \pm 0.10^{c}$ & $261.19 \pm 7.69 \mathrm{e}$ & $2320.43 \pm 153.61^{a}$ & $0.54 \pm 0.03^{a}$ & $0.87 \pm 0.01^{a}$ \\
\hline GM80 & $2.50 \pm 0.07^{\mathrm{b}}$ & $8.45 \pm 0.43^{c}$ & $243.83 \pm 2.22^{\mathrm{d}}$ & $3400.64 \pm 255.33^{b}$ & $0.69 \pm 0.02^{\mathrm{c}}$ & $0.86 \pm 0.01^{a}$ \\
\hline GM70 & $4.00 \pm 0.35^{\mathrm{d}}$ & $7.80 \pm 0.06^{\mathrm{abc}}$ & $242.96 \pm 0.09^{\mathrm{cd}}$ & $3637.07 \pm 259.45^{\mathrm{bc}}$ & $0.75 \pm 0.01^{\mathrm{d}}$ & $0.87 \pm 0.01^{a}$ \\
\hline GM60 & $5.15 \pm 0.07^{\mathrm{f}}$ & $6.68 \pm 0.23^{a}$ & $224.13 \pm 2.26^{\mathrm{ab}}$ & $4088.90 \pm 344.78^{\mathrm{de}}$ & $0.76 \pm 0.01^{\mathrm{de}}$ & $0.86 \pm 0.01^{a}$ \\
\hline
\end{tabular}

Değerler ortalama \pm standart sapma olarak verilmiştir.

a-f: Aynı kolonda farklı harflerle gösterilen ortalamalar arasındaki fark istatistiksel olarak anlamlıdır $(P<0.05)$

$V$ alues are given as means \pm standard deviations

a-f: The difference between the means indicated by different letters in the same column is statistically significant $(P<0.05)$

\section{Renk özellikleri}

Renk ölçüm sonuçları Çizelge 3'te verilmiştir.

Renk ölçüm sonuçlarına göre örneklerin $L^{*}$ değeri

75.35-78.97, $a^{*}$ değeri 16.32-19.52 ve $b^{*}$ değeri
25.64-28.32 aralığında değişmektedir. Karışımlarda mercimek unu oranının arturilmasiyla parlaklık parametresinde $\left(L^{*}\right)$ azalma gözlenmiştir $(P<0.05)$. Guar zamkı ilavesi olan 
örneklerde ise GM90 ve GM60 örneklerinin $L^{*}$ değerinde artış görülmüştür $(P<0.05)$. Karışımda mercimek unu oranının artırılmasıyla erişte örneklerinin kırmızllık değerinde $\left(a^{*}\right)$ artış gözlenmiştir. Benzer şekilde, Bae vd. (2016) tarafından yapılan bir çalışmada kırmızı mercimek unu içeren eriştelerin artan mercimek unu oranıyla $L^{*}$ değeri azalırken, $a^{*}$ değerinin arttı̆̆1 tespit edilmiştir. Kırmızı rengin oluşması Maillard reaksiyonu ile ilişkili enzimatik olmayan esmerleşmeye de bağlı olabilmektedir (Mościcki vd., 2007). Örneklerin sar1 renk değerleri (b*) incelendiğinde, $\% 90$ oranında mercimek unu içeren M90 örneğinde en düşük $b^{*}$ değeri tespit edilmiştir. GM60 örneğinin dışında, guar zamkı ilavesi olan örneklerin $b^{*}$ değerinin arttı̆̆1 gözlenmiştir $(P$ <0.05). Zamk ilavesi olan örneklerde, $b^{*}$ değerindeki artışın, kullanılan guar zamkının renginden kaynaklanmış olabileceği düşünülmektedir.

Çizelge 3. Eriştelerin renk özellikleri

Table 3. Colour of noodle samples

\begin{tabular}{lccc}
\hline $\begin{array}{l}\text { Örnek } \\
\text { Samples }\end{array}$ & $L^{*}$ & $a^{*}$ & $b^{*}$ \\
\hline M90 & $75.35 \pm 0.31^{\mathrm{a}}$ & $19.52 \pm 0.27 \mathrm{~g}$ & $25.64 \pm 0.60^{\mathrm{a}}$ \\
M80 & $76.70 \pm 0.63^{\mathrm{b}}$ & $18.50 \pm 0.16^{\mathrm{e}}$ & $26.77 \pm 0.38^{\mathrm{bc}}$ \\
M70 & $78.08 \pm 0.2^{\mathrm{d}}$ & $17.34 \pm 0.04^{\mathrm{c}}$ & $26.63 \pm 0.31^{\mathrm{bc}}$ \\
M60 & $78.49 \pm 0.20^{\mathrm{d}}$ & $16.65 \pm 0.12^{\mathrm{b}}$ & $26.12 \pm 0.56^{\mathrm{ab}}$ \\
GM90 & $76.57 \pm 0.26^{\mathrm{b}}$ & $18.68 \pm 0.15^{\mathrm{f}}$ & $27.85 \pm 0.69 \mathrm{de}$ \\
GM80 & $76.71 \pm 0.73^{\mathrm{b}}$ & $17.71 \pm 0.12^{\mathrm{d}}$ & $28.32 \pm 0.53^{\mathrm{e}}$ \\
GM70 & $77.47 \pm 0.33^{\mathrm{c}}$ & $16.77 \pm 0.07 \mathrm{~b}$ & $27.21 \pm 0.61_{\mathrm{cd}}$ \\
GM60 & $78.97 \pm 0.35^{\mathrm{e}}$ & $16.32 \pm 0.06^{\mathrm{a}}$ & $26.32 \pm 0.97 \mathrm{ab}$ \\
\hline
\end{tabular}

Değerler ortalama \pm standart sapma olarak verilmiştir.

a-g: Aynı kolonda farklı harflerle gösterilen ortalamalar arasındaki fark istatistiksel olarak anlamlıdır $(P<0.05)$

$V$ alues are given as means \pm standard deviations

a-g: The difference between the means indicated by different letters in the same column is statistically significant $(P<0.05)$

\section{Genişleme oranı}

Genişleme oranı sonuçları Çizelge 4'te verilmiştir. Erişte örneklerinin genişleme oranı değerleri 0.941.41 arasında değişmektedir. Örneklerde mercimek unu oranı arttıkça genişleme oranı değerlerinin azaldığ1 görülmüştür. Genişleme oranındaki değişim, hammaddelerde protein ve lif içeriğinin yüksek olması ve toplam nişasta içeriğinin düşük olması ile ilişkili olabilmektedir (Singh vd., 2007; Wójtowicz ve Mościcki, 2014). Mercimek unu oranı arttıkça, mercimek ununa bağlı olarak protein oranı artmaktadır ve formülasyona eklenen nişasta oranı da azalmaktadır. Proteinlerin, ekstrüzyon ürünlerinin gözenek yapısını etkilediği bilinmektedir. Mısır nişastasına farklı oranlarda soya protein konsantresi ilave edilerek üretilen ekstrüzyon ürünlerinde, kullanılan soya protein konsantresi oranı artırldıkça genişleme indeksi değerlerinin azaldığ1 bildirilmiştir (de Mesa vd., 2009). Zamk ilavesinin etkisi incelendiğinde, sadece M60 ve GM60 örnekleri arasında istatistiksel olarak anlamlı bir fark bulunmuştur $(P<0.05)$. Bununla birlikte, zamk ilavesi içermeyen M60 örneğinin tüm erişte örnekleri arasında en yüksek genişleme oranına sahip olduğu tespit edilmiştir.

\section{Yığın yoğunluğu}

Ürün gözenekliliğinin bir göstergesi olan yığın yoğunluğu, ambalaj tasarımını etkileyen ve ambalaj materyalinin türünü belirlemek için de kullanılabilen bir özelliktir. Düşük yığın yoğunluğu erişte için önemlidir ve istenmektedir (Rathod ve Annapure, 2017). Erişte örneklerinin 
yığın yoğunluğu değerleri $1.27-1.36 \mathrm{mg} / \mathrm{mm}^{3}$ arasında değişmektedir. Yığın yoğunluğunun, karışımdaki mercimek unu oranından etkilendiği görülmüştür. Eriştelerin yığın yoğunluğu, mercimek unu oranındaki artış ile birlikte artmıştır. Artan mercimek ununa bağlı olarak karışımda artan protein oranı göz önüne alınırsa, protein-nişasta reaksiyonlan ile ilişki olabileceği düşünülmektedir. Şeker (2005) tarafindan yapılan çalışmada, protein-nişasta reaksiyonlarının amilopektin zincirlerinin serbest genişlemesini azaltabileceği, ekstrüzyon sırasında su buharının salınmasını engelleyerek genişlemeyi sınırlayabileceği ve yoğunluğu artırabileceği bildirilmiştir. Ayrica Wang vd. (1999) tarafindan genişleme oranı ve yığın yoğunluğu arasında zıt ilişki olduğu gözlenmiştir. Guar zamkı ilavesi olan GM80 ve GM70 örneklerinde zamk katılmayan formülasyonlara kıyasla yığın yoğunluğu azalırken, GM90 örneğinde artış görülmüştür.

Çizelge 4. Erişte örneklerinin genişleme oranı, yığın yoğunluğu, suda çözünebilirlik indeksi, su absorbsiyon indeksi değerleri

Table 4. Expansion ratio, bulk density, water solubility index, water absorption index values of noodle samples

\begin{tabular}{lcccc}
\hline $\begin{array}{l}\text { Örnek } \\
\text { Samples }\end{array}$ & $\begin{array}{c}\text { Genişleme Oranı } \\
\text { Expansion ratio }\end{array}$ & $\begin{array}{c}\text { Yiğın Yoğunluğu } \\
\left(\mathrm{mg} / \mathrm{mm}^{3}\right) \\
\text { Bulk } \\
\text { density }\left(\mathrm{mg} / \mathrm{mm}^{3}\right)\end{array}$ & $\begin{array}{c}\text { WSI }(\%) \\
\text { WSI } \%)\end{array}$ & $\begin{array}{c}\text { WAI (g jel /g) } \\
\text { WAI }(g \text { gel /g) }\end{array}$ \\
\hline M90 & $0.94 \pm 0.04^{\mathrm{a}}$ & $1.35 \pm 0.02^{\mathrm{de}}$ & $19.33 \pm 0.54^{\mathrm{d}}$ & $4.39 \pm 0.15^{\mathrm{c}}$ \\
M80 & $1.06 \pm 0.02^{\mathrm{b}}$ & $1.34 \pm 0.01^{\mathrm{cde}}$ & $17.77 \pm 0.59^{\mathrm{c}}$ & $4.81 \pm 0.24^{\mathrm{d}}$ \\
M70 & $1.19 \pm 0.09^{\mathrm{c}}$ & $1.33 \pm 0.01^{\mathrm{cd}}$ & $17.67 \pm 1.55^{\mathrm{c}}$ & $5.35 \pm 0.19 \mathrm{e}$ \\
M60 & $1.52 \pm 0.05^{\mathrm{e}}$ & $1.27 \pm 0.02^{\mathrm{a}}$ & $13.71 \pm 0.30^{\mathrm{a}}$ & $5.86 \pm 0.07 \mathrm{~g}$ \\
GM90 & $0.97 \pm 0.02^{\mathrm{a}}$ & $1.36 \pm 0.01^{\mathrm{e}}$ & $20.29 \pm 0.16^{\mathrm{d}}$ & $3.08 \pm 0.04^{\mathrm{a}}$ \\
GM80 & $1.03 \pm 0.01^{\mathrm{b}}$ & $1.32 \pm 0.01^{\mathrm{c}}$ & $17.73 \pm 0.09^{\mathrm{c}}$ & $4.12 \pm 0.03^{\mathrm{b}}$ \\
GM70 & $1.19 \pm 0.02^{\mathrm{c}}$ & $1.30 \pm 0.01^{\mathrm{b}}$ & $16.05 \pm 0.32^{\mathrm{b}}$ & $4.92 \pm 0.03^{\mathrm{d}}$ \\
GM60 & $1.41 \pm 0.06^{\mathrm{d}}$ & $1.27 \pm 0.03^{\mathrm{a}}$ & $15.06 \pm 0.35^{\mathrm{b}}$ & $5.61 \pm 0.02^{\mathrm{f}}$ \\
\hline
\end{tabular}

Değerler ortalama \pm standart sapma olarak verilmiştir.

a-g: Aynı kolonda farklı harflerle gösterilen ortalamalar arasındaki fark istatistiksel olarak anlamlıdır $(P<0.05)$

$V$ alues are given as means \pm standard deviations

a-g: The difference between the means indicated by different letters in the same column is statistically significant $(P<0.05)$

Suda çözünürlük indeksi (WSI) ve su absorbsiyon indeksi (WAI)

WAI ve WSI değerleri genellikle nişastanın jelatinizasyon ve bozunma derecesi ile ilgilidir. WSI, ekstrüzyondan sonra protein ve diğer moleküllerden salınan çözünür bileşenlerin miktarını ölçmektedir (Rathod ve Annapure, 2017). Yüksek WSI değeri, in vitro sindirilebilirliğin de iyi bir göstergesidir (Guha vd., 1997). Bu çalışmada, mercimek unu oranının ekstrüde erişte örneklerinin WAI ve WSI değerleri üzerinde etkili olduğu belirlenmiştir $(P<0.05)$. M90 kodlu \%90 mercimek unu içeren örnekte en yüksek WSI değeri tespit edilmiştir ve mercimek unu oranının artırılmasıyla, WSI değerlerinin de arttı̆̆ gözlenmiştir. Zamk içeren formülasyonlar arasinda ise GM90 kodlu \%90 mercimek unu içeren örneğin en yüksek WSI değerine sahip olduğu belirlenmiştir. Wójtowicz ve Mościcki
(2014) tarafından yapılan çalışmada, mercimek, sarı bezelye ve kuru fasülye gibi baklagil unları ile zenginleştirilen makarnaların WSI değerleri karşlaş̧tırlmış; 20-40 g/100 g baklagil unu içeren makarna örneklerinin $10 \mathrm{~g} / 100 \mathrm{~g}$ baklagil unu içeren örneklere göre daha yüksek WSI değerine sahip olduğu gözlenmiştir. Erişte formülasyonlarına ilave edilen guar zamk1, sadece GM60 örneğinin WSI değerinde anlamlı bir artışa sebep olmuştur $(P<0.05)$. WAI değerlerinin, artan mercimek unu oraniyla azaldığ1 görülmüştür. Guar zamkı ilave edilen örneklerin WAI değerinin guar zamkı içermeyen örneklere kıyasla daha düşük olduğu bulunmuştur. Bunun yanında erişte örnekleri incelendiğinde WAI değeri arttıkça, WSI değerinin azaldığı gözlenmiştir. Genel olarak, ekstrüde edilmiş nişastalı ürünlerde, örneklerin WAI değeri arttıkça, WSI değerinin azalması birçok 
araştırmacı tarafindan tespit edilmiştir (Colonna vd., 1984; Iwe ve Onuh, 1992).

\section{Mikroyap1}

Ekstrüde erişte örneklerinin mikroyapısı, Şekil 1'de gösterilmiştir. SEM üzerinde gözlemlenen erişte örneklerinin mikroyapısı incelendiğinde, örneklerin yüzeyinin, mercimek unu oranından ve guar zamkı ilavesinden etkilendiği görülmüştür. Erişte örneklerinin mercimek unu oranı arttıkça yüzeyde pürüzlülüğün arttğı gözlenmiştir. Bouasla vd. (2017) tarafindan yürütülen bir çalışmada pirinç ununa ilave edilen kırmızı mercimek unu oranınin artırlmasiyla pürüzlülüğün de artmış olduğu belirtilmiştir. Bununla birlikte, Wójtowicz ve Mościcki (2014) tarafindan yapılan çalışmada ekstrüzyonla pişirme ile oluşturulan zenginleștirilmiş makarnanın kesit örneklerinde nişasta-protein ağına sıkıca bağlı ögütülmüş mercimeğe ait olduğu düşünülen parçacıklar görülmüştür. Bu çalsşmada da benzer
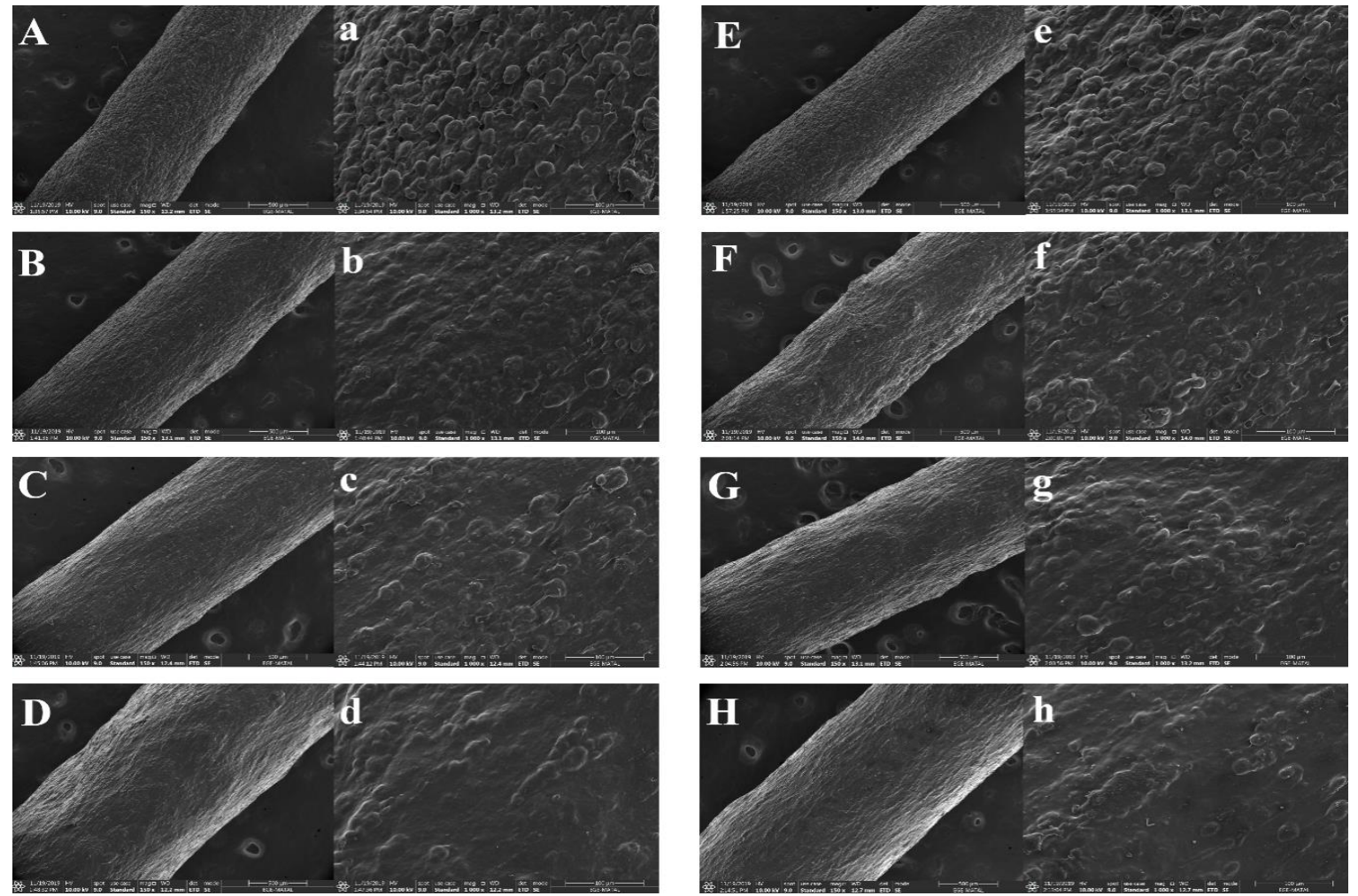

Şekil 1. Pişmemiş erişte örneklerinin yüzey mikroyapısı (A-H: 150X büyütme, a-h: 1000X büyütme): M90 (A,a), M80 (B,b), M70 (C,c), M60 (D,d), GM90 (E,e), GM80 (F,f), GM70 (G,g), GM60 (H,h) Figure 1. Surface microstructure of uncooked noodle samples (A-H: 150X magnification, a-b: 1000X magnification): $\operatorname{M90}(A, a), M 80(B, b), M 70(C, c), M 60(D, d), G M 90(E, e), \operatorname{GM} 80$ (F,f), GM70 (G,g), GM60 (H,h) 


\section{SONUÇ}

Dünya genelinde sağllklı beslenme konusunda tüketici bilinci ve sağlıklı gidaya olan talep artmaktadır. Bunun yanında yoğun yaşam biçimi, kolay ve çabuk hazırlanan gidaların üretimini gerektirmektedir. Bu yüzden baklagil unlarından ekstrüde erişte üretimi tüketici isteklerinin kesişim noktas1 olabilmektedir. Mercimek unu kullanılarak hazırlanan eriştelerde $a^{*}$ değerinin, mercimek oranı arttıkça arttığ1 görülmüştür. Bunun yanında mercimek unu oranı ve pişme süresi arasında negatif bir ilişki gözlenmiştir. Guar zamkının ilave edildiği örneklerde ise pişme sürelerinin, guar zamk1 ilavesi olmayan örneklere kıyasla daha fazla olduğu tespit edilmiştir. Örneklerin pişme kayıpları istenilen değerler arasinda olup, guar zamk1 ilavesiyle, sadece $\% 70$ ve $\% 60$ mercimek unu içeren örneklerde pişme kaybı değerlerinin azaldığ gözlenmiştir $(P<0.05)$. Örneklerin doku sonuçlarına göre, guar zamk1 ilavesinin \%90 mercimek unu içeren örneğin sertlik değerinde anlamlı bir etkisi olmazken $(P$ $>0.05$ ), diğer erişte örneklerinin sertlik değerini azalttığ1 gözlenmiştir. Mercimek unu oranı ve zamk ilavesi gözetmeksizin örneklerin elastikiyet değerlerinde anlamlı bir etki görülmemiştir ( $P$ $>0.05)$. Mercimek unu oranının artmasına bağlı olarak örneklerin yapışkanlık değerleri azalmıştır. Mercimek unu oranı arttıkça örneklerin genişleme oranı azalmıştır ve guar zamkının ilavesinin GM60 örneği dışında, genişleme oranına anlamlı bir etkisi olmadığı belirlenmiştir $(P>0.05)$. Mercimek unu oranı arttıkça, örneklerin yığın yoğunluğunda artış gözlenmiştir. Örneklerin mikroyapıları incelendiğinde, mercimek unu oranı azaldıkça eriştelerin yüzeyindeki pürüzlülügün azaldığ1 ve zamk ilavesinin biraz pürüzlülüğü artırdığ1 saptanmıştır.

Hazır eriştelerin rengi, pişme kalitesi ve pişirilmiş eriştelerin dokusu en önemli kalite özellikleri olarak kabul edilir. Erişteler pişirildikten sonra sıkı kalmalı ve pişirme suyunda az miktarda katı madde bulunan kısa pişirme süresine sahip ürünler olmalıdır. Bu çalışma sonucunda kabul edilebilir kalite özelliklerine (kısa pişme süresi ve düşük pişme kaybı, doku ve renk özellikleri, yüksek su absorpsiyonu) sahip olan örneğin GM80 (\%80 oranında mercimek unu içeren guar zamk1 ilaveli örnek) olduğu sonucuna varılmıştır.

\section{ÇIKAR ÇATIŞMASI}

$\mathrm{Bu}$ makalede yazarların, diğer kişilerin ve kurumların arasında bir çıkar çatışması yoktur.

\section{YAZAR KATKILARI}

Şebnem Tavman, Seher Kumcuoğlu makale konusunu araşturdı ve tasarladı. Merve Vatansever, Burcu Havva Tiğa deneysel çalışmaları gerçekleştirdi ve makalenin taslağını oluşturdu. Tüm yazarlar makalenin yazımına katkıda bulundu, son halini okudu ve onayladı.

\section{TEŞEKKÜR}

Ege Üniversitesi Bilimsel Araşturma Projeleri Koordinatörlüğ̈̈ [Proje No: FYL-2019-20751] tarafindan desteklenmiştir.

\section{KAYNAKLAR}

AACCI, (2000). AACC International Approved Methods of Analysis, AACC International, St. Paul, MN. (Method 66-50.01).

Adsule, R.N., Kadam, S.S. (1989). Proteins. In D.K. Salunkhe and S.S. Kadam (Eds.). Handbook of world food legumes nutritional chemistry processing technology and utilization. Boca Raton: Florida US: CRC Press Inc, 1: 75-97.

Afifah, N., Ratnawati, L. (2017, December). Quality assessment of dry noodles made from blend of mocaf flour, rice flour and corn flour. In IOP Conference Series: Earth and Environmental Science (Vol. 101, No. 1, p. 012021). IOP Publishing.

Alam, M.S., Kaur, J., Khaira, H., Gupta, K. (2016). Extrusion and extruded products: changes in quality attributes as affected by extrusion process parameters : A review, Crit Rev Food Sci Nutr, 56: 445- 473.

Alloncle, M., Doublier, J.L. (1991). Viscoelastic properties of maize starch/hydrocolloid pastes and gels. Food Hydrocoll, 5: 455-467.

Alvarez-Martinez, L., Kondury, K.P., Harper, J.M. (1988). A general model for expansion of extruded products. J Food Sci, 53(2): 609-615.

Aravind, N., Sissons, M., Fellows, C.M. (2012). Effect of soluble fibre (guar gum and carboxymethylcellulose) addition on 
technological, sensory and structural properties of durum wheat spaghetti. Food Chem, 131(3): 893900.

Bae, D.B., Kim, K.H., Yook, H.S. (2016). Quality characteristics of noodles added with red lentil powder. J Korean Soc Food Sci Nutr, 45(9): 13381343 [in Korean].

Bouasla, A., Wójtowicz, A., Zidoune, M.N. (2017). Gluten-free precooked rice pasta enriched with legumes flours: Physical properties, texture, sensory attributes and microstructure. LWT-Food Sci Technol, 75: 569-577.

Cabrera-Chávez, F., de la Barca, A.M.C., IslasRubio, A.R., Marti, A., Marengo, M., Pagani, M.A., Iametti, S. (2012). Molecular rearrangements in extrusion processes for the production of amaranth-enriched, gluten-free rice pasta. LWT-Food Sci Technol, 47(2): 421-426.

Cho S.Y., Lee J.W., Rhee Ch. (2010). The cooking qualities of microwave oven cooked instant noodles. Int J Food Sci Technol, 45: 1042-1049.

Choy, A.L., Bee, K.M., Darryl, M.S. (2012). The effects of acetylated potato starch and sodium carboxymethyl cellulose on the quality of instant fried noodles. Food Hydrocoll, 26(1): 2-8.

Choy, A.L., Morrison, P.D., Hughes, J.G., Marriott, P.J. Small, D.M. (2013). Quality and antioxidant properties of instant noodles enhanced with common buckwheat flour. J Cereal Sci, 57(3): 281-7.

Colonna, P., Doublier, J.L., Melcion, J.P., Monredon, F.D., Mercier, C. (1984). Extrusion cooking and drum drying of wheat starch. I. Physical and macromolecular modifications. Cereal Chem, 61: 538-543.

de Mesa, N.J.E., Alavi, S., Singh, N., Shi, Y.C., Dogan, H., Sang, Y. (2009). Soy protein-fortified expanded extrudates: Baseline study using normal corn starch. J Food Eng, 90(2): 262-270.

Dewi, E.N. (2011). Quality evaluation of dried noodle with seaweeds pure substitution. $J$ Coast Dev, 14: 151-158.

Ding, Q.B., Ainsworth, P., Tucker, G., Marson, H. (2005). The effect of extrusion conditions on the physicochemical properties and sensory characteristics of rice-based expanded snacks. $J$ Food Eng, 66(3): 283-289.

Fox, J.E. (1997). Seed gums, In: Hydrocolloid applications (A. Nussinovitch, ed.) Chapman and Hall, Springer, US, pp. 140-153.

Frias, J., Giacomino, S., Peñas, E., Pellegrino, N., Ferreyra, V., Apro, N. (2011). Assessment of the nutritional quality of raw and extruded Pisum sativum L. var. laguna seeds. LWT - Food Sci Technol, 44: 1303-1308.

Ganesan, K., Xu, B. (2017). Polyphenol-rich lentils and their health promoting effects. Int J Mol Sci, 18(11): 2390.

Gernah, G.I., Ariahu, G.C. Ingbian, E.K. (2011). Effect of malting and lactic fermentation on some chemical and functional properties of maize. $A m$ J Food Tech, 16: 404-412.

Guha, M., Ali, S.Z., Bhattacharya, S. (1997). Twinscrew extrusion of rice flour without a die: Effect of barrel temperature and screw speed on extrusion and extrudate characteristics. J Food Eng, 32: 251-267.

Gularte, M.A., Rosell, C.M. (2011). Physicochemical properties and enzymatic hydrolysis of different starches in the presence of hydrocolloids. Carbohydr Polym, 85(1): 237-244.

Hall, C., Hillen, C., Robinson, J.G. (2017). Composition, nutritional value, and health benefits of pulses. Cereal Chem, 94: 11-31.

Hatcher, D.W., Kruger, J.E., Anderson, M.J. (1999). Influence of water absorption on the processing and quality of oriental noodles. Cereal Chem, 76(4): 566-572.

Iwe, M.O., Onuh, J.O. (1992). Functional and sensory property of soybean and sweet potato flour mixture. LWT - Food Sci Technol, 25: 569573.

Kaur, A., Singh, N., Kaur, S., Katyal, M., Virdi, A.S., Kaur, D., Ahlawat, A.K., Mahendru-Singh, A. (2015). Relationship of various flour properties with noodle making characteristics among durum wheat varieties. Food Chem, 188: 517-526. 
Kaur, M., Sandhu, K.S., Lim, S.T. (2010). Microstructure, physicochemical properties and in vitro digestibility of starches from different Indian lentil (Lens culinaris) cultivars. Carbohydr Polym, 79(2): 349-355.

Kim, S.G. (1996). Instant noodles, In: Pasta and noodle technology. J.E. Kruger, R.B. Matsuo, and J.W. Dick, EDS., AACC (Am Assoc Cereal Chem) Monogr, St. Paul, MN, the USA, pp. 195-225.

Kim, Y.S., Weisenborn, D.P., Lorenzen, J.H., Berglund, P. (1996). Suitability of edible bean and potato starch noodles. Cereal Chem, 73: 302-308.

Kumoro, A.C., Johnny, D., Alfilovita, D. (2016). Incorporation of microalgae and seaweed in instant fried wheat noodles manufacturing: nutrition and culinary properties study. IFRJ-Int Food Res J, 23(2): 715-722.

Lee, Y.P., Puddey, I.B., Hodgson, J.M. (2008). Protein, fibre and blood pressure: potential benefit of legumes. Clin Exp Pharmacol Physiol, 35(4): 473-476.

Mestres, C., Colonna, P., Buleon, A. (1988). Characteristics of starch networks within rice flour noodles and mungbean starch vermicelli. $J$ Food Sci, 53(6): 1809-1812.

Mościcki, L., Mitrus, M., Wójtowicz, A. (2007). Technika ekstruzji w przemyśle rolnospożywczym. Państwowe Wydawnictwo Rolnicze $i$ Leśne [in Polish].

Mudgil, D., Barak, S., Khatkar, B.S. (2014). Guar gum: processing, properties and food applications-a review. J Food Sci Technol, 51(3): 409-418.

Noda, T., Fujikami, S., Miura, H., Fukushima, M., Takigawa, S., Matsuura-Endo, C., Yamauchi, H. (2006). Effect of potato starch characteristics on the textural properties of Korean-style cold noodles made from wheat flour and potato starch blends. Food Sci Technol Res, 12(4): 278-283.

Park, C.S., Baik, B.K. (2004). Significance of amylose content of wheat starch on processing and textural properties of instant noodles. Cereal Chem, 81(4): 521-526.
Rathod, R.P., Annapure, U.S. (2017). Physicochemical properties, protein and starch digestibility of lentil based noodle prepared by using extrusion processing. LWT - Food $S_{c i}$ Technol, 80: 121-130.

Riaz, M.N. (2001). Selecting the right extruder. In: Extrusion cooking-Technologies and Applications, Guy, R. (ed.), Woodhead Publishing Limited, Cambridge, the UK, pp. 29-49.

Schoenlechner, R., Drausinger, J., Ottenschlaeger, V., Jurackova, K., Berghofer, E. (2010). Functional properties of gluten-free pasta produced from amaranth, quinoa buckwheat. Plant Foods Hum Nutr, 65: 339-349.

Seker, M. (2005). Selected properties of native or modified maize starch/soy protein mixtures extruded at varying screw speed.J Sci Food Agric, 85(7): 1161-1165.

Shi, X.H., BeMiller, J.N. (2002). Effects of food gums on viscosities of starch suspensions during pasting. Carbobydr Polym, 50: 7-18.

Singh, B., Sekhon, K.S., Singh, N. (2007). Effects of moisture, temperature and level of pea grits on extrusion behaviour and product characteristics of rice. Food Chem, 100 (1): 198-202.

Singh, N., Singh, J., Sodhi, N.S. (2002). Morphological, thermal, rheological and noodlemaking properties of potato and corn starch. J Sci Food Agric, 82: 1376-1383.

Singh, S., Gamlath, S., Wakeling, L. (2007). Nutritional aspects of food extrusion: a review. Int J Food Sci Technol, 42(8): 916-929.

Smith, O.B. (1971). Why use extrusion? Paper presented at the XII. annual Central States Section of the American Association of Cereal Chemists, 12-13 February, St Louis, MO, the USA.

Stephen, A.M., Dahl, W.J., Sieber, G.M., van Blaricom, J.A., Morgan, D.R. (1995). Effect of green lentils on colonic function, nitrogen balance, and serum lipids in healthy human subjects. Am J Clin Nutr, 62(6): 1261-1267.

Teterycz, D., Sobota, A., Zarzycki, P., Latoch, A. (2020). Legume flour as a natural colouring 
component in pasta production. J Food $S_{c i}$ Technol, 57(1): 301-309.

Wang, N., Bhirud, P.R., Sosulski, F.W., Tyler, R.T. (1999). Pasta-like product from pea flour by twin-screw extrusion. J Food Sci, 64(4): 671-678.

Wójtowicz, A., Mościcki, L. (2014). Influence of legume type and addition level on quality characteristics, texture and microstructure of enriched precooked pasta. LWT-Food Sci Technol, 59(2): 1175-1185.

Yu, L.J., Ngadi, M.O. (2006). Rheological properties of instant fried noodle dough as affected by some ingredients. J Sci Food Agric, 86: 544-548. 